Review

\title{
Aquatic Organisms Research with DNA Barcodes
}

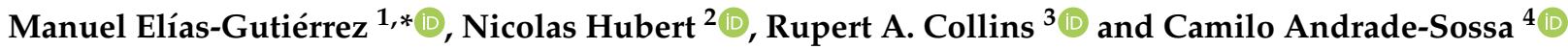 \\ 1 Departamento de Sistemática y Ecología Acuática, El Colegio de la Frontera Sur, Av. Centenario Km.5.5, \\ Chetumal 77014, Mexico \\ 2 UMR 5554 ISEM, IRD, Universite Montpellier, CNRS, EPHE, Université de Montpellier, Place Eugène \\ Bataillon, CEDEX 05, 34095 Montpellier, France; nicolas.hubert@ird.fr \\ 3 School of Biological Sciences, University of Bristol, Life Sciences Building, Bristol BS8 1T, UK; \\ rupertcollins@gmail.com \\ 4 Grupo de Estudios en Recursos Hidrobiológicos Continentales, Departamento de Biología, \\ Universidad del Cauca, Popayán 190002,Colombia; ceandrade@unicauca.edu.co \\ * Correspondence: melias@ecosur.mx
}

check for

updates

Citation: Elías-Gutiérrez, M.; Hubert, N.; Collins, R.A.; Andrade-Sossa, C. Aquatic Organisms Research with DNA Barcodes. Diversity 2021, 13, 306. https://doi.org/10.3390/d13070306

Academic Editor: Eric Buffetaut

Received: 14 May 2021

Accepted: 5 July 2021

Published: 6 July 2021

Publisher's Note: MDPI stays neutral with regard to jurisdictional claims in published maps and institutional affiliations.

Copyright: (c) 2021 by the authors. Licensee MDPI, Basel, Switzerland. This article is an open access article distributed under the terms and conditions of the Creative Commons Attribution (CC BY) license (https:// creativecommons.org/licenses/by/ $4.0 /)$.

\begin{abstract}
Since their inception, DNA barcodes have become a powerful tool for understanding the biodiversity and biology of aquatic species, with multiple applications in diverse fields such as food security, fisheries, environmental DNA, conservation, and exotic species detection. Nevertheless, most aquatic ecosystems, from marine to freshwater, are understudied, with many species disappearing due to environmental stress, mostly caused by human activities. Here we highlight the progress that has been made in studying aquatic organisms with DNA barcodes, and encourage its further development in assisting sustainable use of aquatic resources and conservation.
\end{abstract}

Keywords: aquatic life; biodiversity; freshwater; marine; brackish; invertebrate; fish; crustacea; insecta

\section{Introduction}

Since its inception as an ambitious global bioidentification system [1], DNA barcodingthe use of a standardized gene fragment as an internal tag for species identificationhas established itself as an important method in biodiversity sciences, with more than 12,000 papers published (Web of Science search "DNA" and "barcod"”, 10 June 2021). The initial proposal by Hebert and collaborators recommended the mitochondrial cytochrome c oxidase I (COI) marker for animals. However, in the case of plants and fungi, other more effective markers have been proposed, such as the maturaseK (matK) and ribulose biphosphate carboxylase large subunit (rbcL) choloroplast markers for flowering plants [2]. Several markers have been suggested as DNA barcodes for diatoms, for example, from $5.8 \mathrm{~S}+\mathrm{ITS}-2$ [3] to rbcL [4], but studies on these taxa have been limited. For fungi, the ITS has been broadly accepted [5]; however, its implementation also has several problems, particularly in some aquatic species [6], and despite its importance, we found only six papers for DNA barcoding aquatic fungi.

DNA barcoding has been repeatedly demonstrated as a fit-for-purpose method of biodiversity surveying, showing high rates of congruence with traditional taxonomy in well-known groups such as fishes and birds [7-10], while its power as a predictive tool in biodiversity sciences also quickly became apparent, spearheading new molecular frameworks for de novo species discovery [11-13]. Here, some striking examples of overlooked diversity have been observed $[14,15]$, and similar trends have been depicted in numerous aquatic ecosystems. Currently, DNA barcoding can accelerate biodiversity inventories and assist the work of dwindling numbers of taxonomists in many countries. The importance of data sharing and potential for collaborative research was recognized early on, resulting in the creation of the Barcode of Life Data System (BOLD) [16]. Sequence data could be associated with detailed specimen metadata and photographs, supporting trace files, and most importantly vouchered specimens in museum collections [16]. The 
online workbench also provides the Barcode Index Number (BIN) system, equivalent to a Molecular Operational Taxonomic Unit (MOTU) for all specimens that cover minimal data standards [12], creating a standardized referencing tool for unidentified organisms.

In this overview, we will cover recent trends in the study of aquatic life with DNA barcodes and highlight examples illustrating its utility.

\section{Progress in Aquatic DNA Barcoding Studies}

General assessments of the use of DNA barcodes in the marine realm were provided in 2011 [17] and 2016 [18], when the number of DNA barcoding studies on aquatic biotas was somewhat less than around 160 per year (Figure 1A). Since then, that number has increased. As such, there is a clear upward trend of DNA barcoding studies, with more than 2500 hits during the last two years (Figure 1A). The words "barcod" and "DNA" are becoming increasingly used, from zero to more than 1400 hits per year in 2019 and 2020 in the Web of Science database (consulted 10 June 2021) (Figure 1A). However, when we restrict the search to aquatic environments, this figure lowers to 320, with an increment since 2014 (Figure 1B), in comparison with the other trends (Figure 1A) (search "DNA" and "barcod" and "marin" or "aquat" or "freshwat" or "estuar" or "fish" in the Web of Science). Considering that more than $75 \%$ of our planet is represented by aquatic environments, this is a modest increment of DNA barcoding studies on aquatic organisms. This modest increment has had mostly the fishes as focal group, where the use of DNA barcoding has been more widespread than invertebrates or aquatic plants (Figure 1A).

The majority of studies included marine and freshwater environments (Figure 1B). It is evident that estuarine systems are almost lacking in analyses with DNA barcoding (Figure 1B).

A good account of the barcoding progress in crustaceans was made in 2015 by Raupach and Radulovici [19], who reported a total of 164 studies, with most studies focusing on Decapoda. Progress in understanding the biodiversity of crustaceans is more advanced for marine environments than in freshwater [19].

Barcoding of aquatic insects has seen most progress in Europe, with Germany the most advanced country, although the diversity there is not high [20,21] compared with the neotropics or the tropics. Here, new species are regularly discovered [22], for example in Cameroon [23]. However, currently DNA barcoding in these and other regions is limited $[24,25]$. Between North America and Mexico, where the transition between the Nearctic and Neotropics is found, important studies of aquatic insect diversity have been conducted [24,26]. In China, aquatic insects are now being studied in greater depth [27], where 176 species from four rivers in the northwest were analyzed.

Possibly due to their relevance, charismatic nature, and more advanced taxonomic coverage, 37 DNA barcoding studies of Odonata have been published. Among the most recent, the development of reference libraries, mostly in Europe, have been the focus [28-31]. These studies have been started in other regions of the world as well, such as the Andes [32] and Philippines [33].

Another complex group with aquatic immature stages, the chironomids, are starting to be studied with DNA barcodes, where the focus has been in different speciose genera. such as Tanytarsus, found almost everywhere [34,35], and other speciose groups [36-38].

In some invertebrate groups such as Polychaeta, with more than 10,000 species described, a total of 65 barcoding studies have been published prior to 2020. Copepoda, which are some of the most abundant organisms in our planet [39], encompassing 14,300 species (World Association of Copepoda; @copepodology), have been targeted by only 87 studies so far, with eight and ten in 2019 and 2020, respectively (Figure 1C), despite the seminal study from Bucklin et al. comparing DNA barcodes to the Rosetta stone of marine biodiversity [40]. 

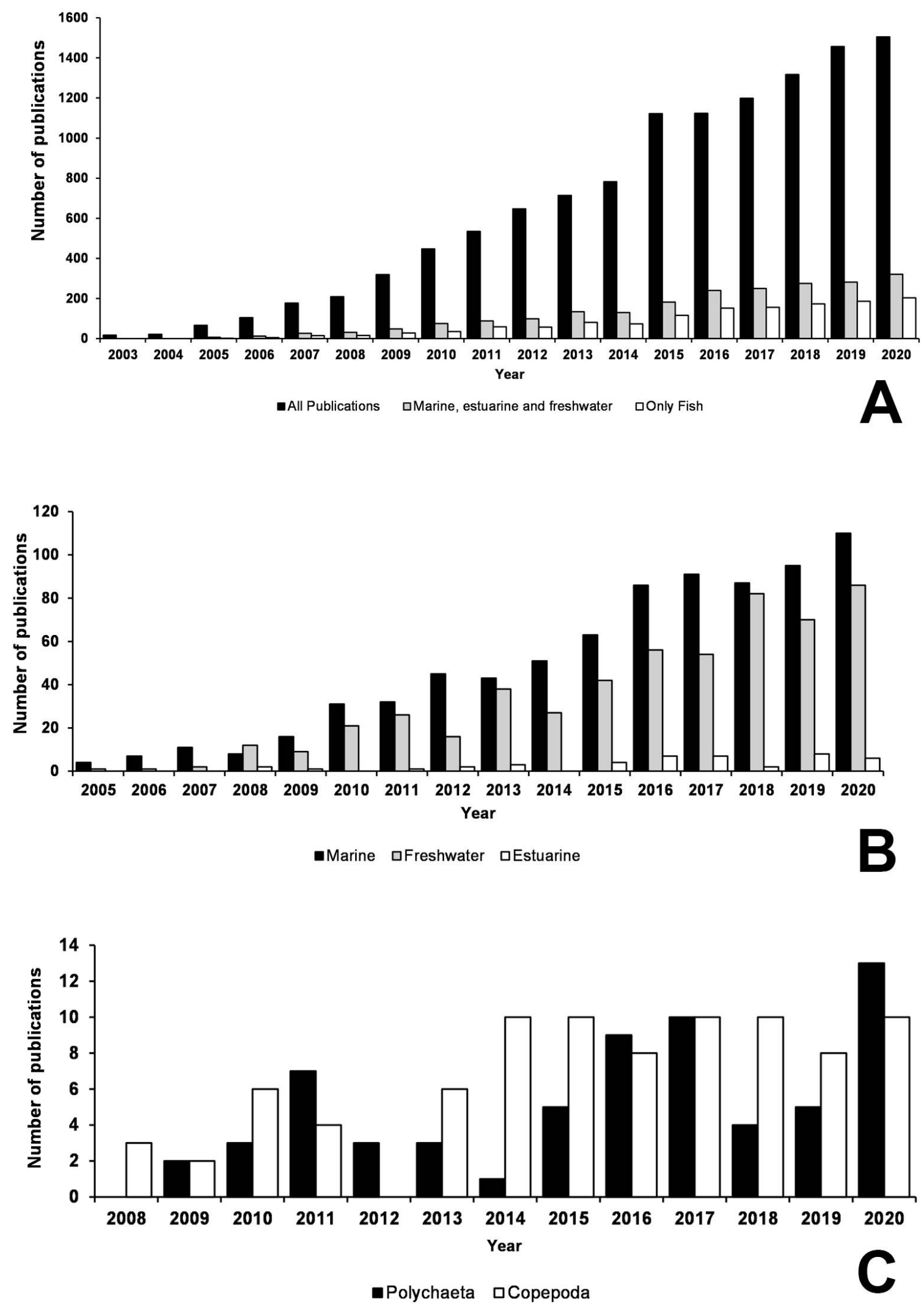

Figure 1. Studies on DNA barcoding on aquatic life. (A) Total studies, including all types of aquatic environments and fishes; (B) Studies in three different aquatic environments; (C) Studies with focus on two of the major groups of aquatic invertebrates. 
This trend likely arises from an assortment of shortcomings hindering the development of DNA barcode as a routine survey tool for several groups. In many specialist groups, there are likely issues obtaining funding and taxonomic expertise required to identify the voucher specimens. In others, there are problems with availability of universal primers for amplifying COI. In copepods, for instance, the target marker has been difficult to amplify reliably, and some researchers proposed to adopt the nuclear $28 \mathrm{~S}$ gene as an alternative marker for COI barcoding [41]. However, $28 \mathrm{~S}$ fails to distinguish between the species of several groups of crustaceans, such as ostracods, and therefore is of limited use as a species diagnostic [42]. Preservation methods also negatively impacted the acquisition of COI sequences in some cases, such as the shift from liquid nitrogen, which damages voucher specimens, to ethanol, which resulted in a lower yield of mitochondrial DNA, as with the cladoceran Holopedium [43]. However, sequencing based on frozen samples with liquid nitrogen proved to increase sequencing success in this case [44]. Due to these problems, new protocols involving cold ethanol were developed with good success in many freshwater zooplankton species, using only a single pair of primers [45].

\section{Species Discovery}

Discovery of unknown biodiversity has been one of the most important contributions of DNA barcoding studies, including in regions hosting seemingly well-known faunas. In Europe, for instance, DNA barcoding revealed that the gammarid Gammarus fossarum encompasses at least 84 MOTUs distributed in 19 European countries [46]. Such levels of cryptic diversity have also been suggested in European odonats [47]. In freshwater fishes, DNA barcodes helped resolve taxonomy of overlooked groups, including some emblematic species such as pike, Esox lucius, which has been split into three distinct species [48], minnows from the genus Phoxinus, with six species now recognized in France [49], as well as putative new species in Telestes pleurobipunctatus [50] and other cypriniformes [51].

The situation is more complicated in the tropics, where biodiversity knowledge gaps are larger and DNA barcoding studies have been conducted in a more piecemeal fashion. Two exceptions are Mexico [52-62] and Brazil [63-72], although both countries are megadiverse hotspots and require much additional effort. Most DNA barcoding studies of tropical aquatic ecosystems have focused on fishes, and frequently report high levels of cryptic and overlooked diversity. These findings include freshwaters of South America [65,73-78], Asia [79-92], and to some extent Africa [93-95]. Similar trends have been observed for tropical marine fishes, particularly in the Indo-Pacific Ocean [96-104]. Overall, efforts to DNA barcode aquatic biotas have been mixed, and the situation in Africa is of most concern. Here, some authors have highlighted that impoverished local scientific capacities curb conservation efforts [105], at the same time as worrying extinction predictions have been observed in some cyprinid fishes [106].

Regarding aquatic invertebrates, studies indicated similar trends. In freshwater mites of Yucatan Peninsula (Mexico), a single DNA barcoding campaign across 24 karstic environments yielded 77 MOTUs, most of them new to science [107]. Similarly, in Panama, a study of invertebrate communities in four streams, with an effort of two hours sampling, yielded 100-106 MOTUs [108]. Similarly, García-Morales et al. [109] detected a complex of 13 species within the rotifera Lecane bulla across 25 localities from south of the United States to Mexico. Elías-Gutiérrez et al. [45] detected a total of 325 BINs among zooplanktonic invertebrates from lakes of Canada and Mexico, with only three BINs (two cladocerans and one copepod) shared between these two countries, suggesting much narrower species distribution ranges in North America freshwater zooplankton than previously thought. Moreover, in an important oligotrophic lake hosting the largest stromatolites in the world [110], the number of possible species increased from about 20 to more than 80 , with a projection near to 120 [45]. The closeness (about $100 \mathrm{~m}$ ) of this lake to a nearby deep sinkhole $(64 \mathrm{~m})$ shows almost an entirely different zooplanktonic fauna, explained by a different chemistry of the water [111-113]. 
In Asia, multiple cases of cryptic diversity have been detected among freshwater shrimps [114-117], other crustaceans and invertebrates [118-123], and parasites [124,125] with implications in conservation and phylogeny [126,127]. Some cases of species under high fishing pressure have been discovered to be complexes of species [128] or unexpected species [129], with important implications for fisheries management. Among African invertebrates, studies are much more limited, mostly focusing on fish parasite communities $[124,130,131]$. Other parasites studied are helminths, which use aquatic invertebrates as intermediate hosts and are of medical importance [23,132-134], and the use of DNA barcoding to identify larval phases has been explored with success [135]. Due to their medical or invasive importance, some studies focused on molluscs [136,137], highlighting three cryptic species in Etheria, for instance [138].

\section{Integrative Taxonomy}

Numerous taxonomic revisions have been conducted using DNA barcodes [139], guiding the detection of diagnostic characters in new species descriptions for marine [140-144] and freshwater organisms [145-150], or assisting in understanding species range distributions $[88,90,118]$. Some important complexes of species-groups, which have been used as indicators of toxicants or live food, have also been explored by integrating DNA barcodes with other source of information such as morphology, biogeography and ecology as part of integrative taxonomy $[151,152]$. Such studies have focused on widely used organisms as biological indicators such as Moina micrura, one of the most ubiquitous freshwater cladocera of the world. Widely used in ecotoxicological studies, DNA barcoding indicated that it constitutes a complex of species, with the nominal species being limited to Eurasia [152]. Species descriptions based on integrative taxonomy of freshwater zooplankton provide an enriched framework, allowing not only the delimitation of species, but also access to a wealth of information guiding the acquisition of additional knowledge about their distributions and biology $[44,119,145-148,153-155]$. Some other groups of marine invertebrates, such as polychaetes, have also been described in an integrative framework [140,142], but a substantial amount of work remains in uncovering the full diversity.

\section{Applications}

Once DNA barcode libraries are available, several applications have been readily demonstrated. In terms of aquatic ecology, DNA barcoding has been used to identify fish larvae [52,56,156-163] and eggs [54] to the species level, with important implications for fisheries or breeding areas' management. In case of invertebrates, DNA barcoding enabled linking early life stages and adults in aquatic insects $[25,164,165]$. Along the same line of application, DNA barcoding has been used for food security [166]. Species substitution of food products has been one of the most studied applications, with more than 50 papers devoted to this topic (search: "food mislabel" and "coi", Web of Science as of 3 March 2021).

The first study of market substitution was published in 2008, focusing on North American seafood, which evidenced $25 \%$ of mislabelling [167], this frequency of replacement being lower in Mexico [168]. Papers dealing with this topic have come from Taiwan [169] and Europe [145-148], mostly devoted to fraud in seafood, and also including some other Latin American countries such as Argentina [149].

Detection and impacts of exotic species has been another promising application, such as the invasion of the lion fish (Pterois volitans) in the Caribbean [55,150], or the Amazon suckermouth catfish Pterygoplichthys in Mexico [151].

\section{Future Trends}

High throughput sequencing (HTS) methods have had a significant impact in DNA barcoding. DNA barcode reference libraries can now be assembled at larger scale and at lower cost [152] and can even be generated on the lab bench or in the field without the requirement for expensive sequencing equipment $[153,154]$. However, the main advances 
have been in DNA metabarcoding; combining HTS with the principals of DNA barcoding has opened a diverse array of applications in terms of species detection and biodiversity monitoring. Of particular relevance in aquatic ecosystems are studies investigating diet ecology and trophic interactions between organisms [155], where in short time passed from Sanger sequencing to study this topic [150] to metabarcoding [170], the structuring and dynamics of plankton communities [156,157], marine benthic biomonitoring [158], and freshwater invertebrate water quality assessment [159]. As well, gut contents can lead to the discovery of unknown biodiversity, as demonstrated in marine and freshwater fishes $[150,171]$. COI barcode reference libraries for animals have now become standard resources for DNA metabarcoding applications, and have been recommended as the standard metabarcode for metazoans [160]. Environmental DNA (eDNA) metabarcoding techniques have also further transformed biodiversity research by extending metabarcoding to include indirect sequencing of animal communities via their trace DNA [161]. These advances have opened up numerous novel applications in aquatic sciences and ecological monitoring $[162,163]$, but further work is required to optimize the use of the COI barcode for these applications [164].

Automation and big data scientific initiatives also have the potential to provide deep insights into aquatic biodiversity and environmental functioning over extended spatial and temporal scales. Here, DNA metabarcoding methods can be combined with machine learning to predict ecological quality [165], or as an automated plankton recorder [156]. In situations where taxonomic information is not available, such as in many understudied invertebrate groups, taxonomy-free MOTUs can be generated and standardized across studies [166]. New developments in public platforms are under development (e.g., mbrave.net), offering solutions in scalability and standardization for HTS-based approaches to biodiversity, biomonitoring, and biosecurity science. The need to expand publicly available databases applies not only to biodiversity discovery, but is also an essential tool in monitoring traded animals $[167,168]$, exotic species, parasites, pathogens, and almost any species present in our planet [169].

Undoubtedly, most aquatic ecosystems on our planet are tragically understudied, particularly in the tropics, and efforts to understand interactions between anthropogenic pressures and global climate change will be only partial, if not flawed, without accurate biodiversity knowledge. With the use of the new bioinformatic tools and DNA barcoding workflows, important contributions to the conservation of marine, brackish and freshwater organisms will be achieved.

Finally, we must clarify that DNA barcodes should never replace the need for taxonomists. On the contrary, DNA barcodes are an additional suite of characters that can be used in taxonomy, and can also assist in the identification of species by non-specialists that require accurate identification of their specimens.

Author Contributions: All authors contributed equally to this review. All authors have read and agreed to the published version of the manuscript.

Funding: This research received no external funding.

Acknowledgments: The authors appreciate all comments from the four reviewers to improve this review.

Conflicts of Interest: The authors declare no conflict of interest.

\section{References}

1. Hebert, P.D.N.; Cywinska, A.; Ball, S.L.; Dewaard, J.R. Biological identifications through DNA barcodes. Proc. R. Soc. B Boil. Sci. 2003, 270, 313-321. [CrossRef] [PubMed]

2. Hubert, N.; Hanner, R.; Holm, E.; Mandrak, N.E.; Taylor, E.; Burridge, M.; Watkinson, D.; Dumont, P.; Curry, A.; Bentzen, P.; et al. Identifying Canadian Freshwater Fishes through DNA Barcodes. PLoS ONE 2008, 3, e2490. [CrossRef]

3. Kerr, K.C.R.; Stoeckle, M.Y.; Dove, C.J.; Weigt, L.A.; Francis, C.M.; Hebert, P.D.N. Comprehensive DNA barcode coverage of North American birds. Mol. Ecol. Notes 2007, 7, 535-543. [CrossRef] [PubMed] 
4. Hebert, P.D.N.; Dewaard, J.R.; Zakharov, E.V.; Prosser, S.W.J.; Sones, J.E.; McKeown, J.T.A.; Mantle, B.; La Salle, J. A DNA ‘Barcode Blitz': Rapid Digitization and Sequencing of a Natural History Collection. PLoS ONE 2013, 8, e68535. [CrossRef] [PubMed]

5. Schmidt, S.; Schmid-Egger, C.; Moriniere, J.; Haszprunar, G.; Hebert, P.D.N. DNA Barcoding Largely Supports 250 Years of Classical Taxonomy: Identifications for Central European Bees (Hymenoptera, Apoidea Partim). Mol. Ecol. Resour. 2015, 15, 985-1000. [CrossRef] [PubMed]

6. Monaghan, M.T.; Wild, R.; Elliot, M.; Fujisawa, T.; Balke, M.; Inward, D.J.; Lees, D.C.; Ranaivosolo, R.; Eggleton, P.; Barraclough, T.; et al. Accelerated Species Inventory on Madagascar Using Coalescent-Based Models of Species Delineation. Syst. Biol. 2009, 58, 298-311. [CrossRef]

7. Ratnasingham, S.; Hebert, P. A DNA-Based Registry for All Animal Species: The Barcode Index Number (BIN) System. PLoS ONE 2013, 8, e66213. [CrossRef]

8. Kekkonen, M.; Hebert, P.D.N. DNA Barcode-Based Delineation of Putative Species: Efficient Start for Taxonomic Workflows. Mol. Ecol. Resour. 2014, 14, 706-715. [CrossRef]

9. Hebert, P.; Penton, E.H.; Burns, J.M.; Janzen, D.H.; Hallwachs, W. Ten species in one: DNA barcoding reveals cryptic species in the neotropical skipper butterfly Astraptes fulgerator. Proc. Natl. Acad. Sci. USA 2004, 101, 14812-14817. [CrossRef]

10. Smith, M.A.; Rodriguez, J.J.; Whitfield, J.B.; Deans, A.; Janzen, D.H.; Hallwachs, W.; Hebert, P. Extreme diversity of tropical parasitoid wasps exposed by iterative integration of natural history, DNA barcoding, morphology, and collections. Proc. Natl. Acad. Sci. USA 2008, 105, 12359-12364. [CrossRef]

11. Ratnasingham, S.; Hebert, P.D.N. Bold: The Barcode of Life Data System (www.Barcodinglife.Org). Mol. Ecol. Notes 2007, 7, 355-364. [CrossRef] [PubMed]

12. Bucklin, A.; Steinke, D.; Blanco-Bercial, L. Barcoding of Marine Metazoa. Annu. Rev. Mar. Sci. 2011, 3, 471-508. [CrossRef]

13. Trivedi, S.; Aloufi, A.A.; Ansari, A.A.; Ghosh, S.K. Role of DNA barcoding in marine biodiversity assessment and conservation: An update. Saudi J. Biol. Sci. 2016, 23, 161-171. [CrossRef]

14. Mauchline, J.; Blaxter, J.H.S.; Southward, A.J.; Tyler, P.A. The Biology of Calanoid Copepods-Introduction. In Advances in Marine Biology; Academic Press: San Diego, CA, USA, 1998; Volume 33, Reprint, Not in File.

15. Bucklin, A.; Ortman, B.D.; Jennings, R.M.; Nigro, L.M.; Sweetman, C.J.; Copley, N.; Sutton, T.; Wiebe, P.A. "Rosetta Stone” for metazoan zooplankton: DNA barcode analysis of species diversity of the Sargasso Sea (Northwest Atlantic Ocean). Deep Sea Res. Part II Top. Stud. Oceanogr. 2010, 57, 2234-2247. [CrossRef]

16. Hirai, J.; Shimode, S.; Tsuda, A.; Hirai, J.; Shimode, S.; Tsuda, A. Evaluation of ITS2-28S as a molecular marker for identification of calanoid copepods in the subtropical western North Pacific. J. Plankton Res. 2013, 35, 644-656. [CrossRef]

17. Karanovic, I.; Huyen, P.T.M.; Yoo, H.; Nakao, Y.; Tsukagoshi, A. Shell and Appendages Variability in Two Allopatric Ostracod Species Seen through the Light of Molecular Data. Contrib. Zool. 2020, 89, 247-269. [CrossRef]

18. Jeffery, N.W.; Elías-Gutiérrez, M.; Adamowicz, S.J. Species Diversity and Phylogeographical Affinities of the Branchiopoda (Crustacea) of Churchill, Manitoba, Canada. PLoS ONE 2011, 6, e18364. [CrossRef]

19. Rowe, C.L.; Adamowicz, S.J.; Hebert, P. Three new cryptic species of the freshwater zooplankton genus Holopedium (Crustacea: Branchiopoda: Ctenopoda), revealed by genetic methods. Zootaxa 2007, 1656, 1-50. [CrossRef]

20. Elías-Gutiérrez, M.; Valdez-Moreno, M.; Topan, J.; Young, M.R.; Cohuo-Colli, J.A. Improved protocols to accelerate the assembly of DNA barcode reference libraries for freshwater zooplankton. Ecol. Evol. 2018, 8, 3002-3018. [CrossRef]

21. Wattier, R.; Mamos, T.; Copilaş-Ciocianu, D.; Jelić, M.; Ollivier, A.; Chaumot, A.; Danger, M.; Felten, V.; Piscart, C.; Žganec, K.; et al. Continental-scale patterns of hyper-cryptic diversity within the freshwater model taxon Gammarus fossarum (Crustacea, Amphipoda). Sci. Rep. 2020, 10, 1-16. [CrossRef]

22. Galimberti, A.; Assandri, G.; Maggioni, D.; Ramazzotti, F.; Baroni, D.; Bazzi, G.; Chiandetti, I.; Corso, A.; Ferri, V.; Galuppi, M.; et al. Italian Odonates in the Pandora's Box: A Comprehensive DNA Barcoding Inventory Shows Taxonomic Warnings at the Holarctic Scale. Mol. Ecol. Resour. 2021, 21, 183-200. [CrossRef] [PubMed]

23. Denys, G.P.J.; Dettai, A.; Persat, H.; Hautecoeur, M.; Keith, P. Morphological and Molecular Evidence of Three Species of Pikes Esox spp. (Actinopterygii, Esocidae) in France, Including the Description of a New Species. C. R. Biol. 2014, 337, 521-534. [CrossRef]

24. Denys, G.P.J.; Dettai, A.; Persat, H.; Daszkiewicz, P.; Hautecoeur, M.; Keith, P. Revision of Phoxinus in France with the Description of Two New Species (Teleostei, Leuciscidae). Cybium 2020, 44, 205-237.

25. Buj, I.; Šanda, R.; Zogaris, S.; Freyhof, J.; Geiger, M.F.; Vukic, J. Cryptic diversity in Telestes pleurobipunctatus (Actinopterygii; Leuciscidae) as a consequence of historical biogeography in the Ionian Freshwater Ecoregion (Greece, Albania). Hydrobiology 2019, 835, 147-163. [CrossRef]

26. Epitashvili, G.; Geiger, M.; Astrin, J.J.; Herder, F.; Japoshvili, B.; Mumladze, L. Towards retrieving the Promethean treasure: A first molecular assessment of the freshwater fish diversity of Georgia. Biodivers. Data J. 2020, 8, e57862. [CrossRef] [PubMed]

27. Valdez-Moreno, M.; Vásquez-Yeomans, L.; Elías-Gutiérrez, M.; Ivanova, N.V.; Hebert, P. Using DNA barcodes to connect adults and early life stages of marine fishes from the Yucatan Peninsula, Mexico: Potential in fisheries management. Mar. Freshw. Res. 2010, 61, 655-671. [CrossRef]

28. Valdez-Moreno, M.; Ivanova, N.V.; Elías-Gutiérrez, M.; Contreras-Balderas, S.; Hebert, P.D.N. DNA Barcodes in Freshwater Fishes from Mexico and Guatemala. J. Fish Biol. 2007, submitted. 
29. Leyva-Cruz, E.; Vásquez-Yeomans, L.; Carrillo, L.; Valdez-Moreno, M. Identifying pelagic fish eggs in the southeast Yucatan Peninsula using DNA barcodes. Genome 2016, 59, 1117-1129. [CrossRef]

30. Vásquez-Yeomans, L.; Carrillo, L.; Morales, S.; Malca, E.; Morris, J.A.; Schultz, T.; Lamkin, J.T. First larval record of Pterois volitans (Pisces: Scorpaenidae) collected from the ichthyoplankton in the Atlantic. Biol. Invasions 2011, 13, 2635-2640. [CrossRef]

31. Victor, B.C.; Vasquez-Yeomans, L.; Valdez-Moreno, M.; Wilk, L.; Jones, D.L.; Lara, M.R.; Caldow, C.; Shivji, M. The larval, juvenile, and adult stages of the Caribbean goby, Coryphopterus kuna (Teleostei: Gobiidae): A reef fish with a pelagic larval duration longer than the post-settlement lifespan. Zootaxa 2010, 2346, 53-61. [CrossRef]

32. Victor, B.C. Hypoplectrus floridae n. sp. and Hypoplectrus ecosur n. sp., Two New Barred Hamlets from the Gulf of Mexico (Pisces: Serranidae): More Than 3\% Different in COI MtDNA Sequence from the Caribbean Hypoplectrus Species Flock. J. Ocean Sci. Found. 2012, 5, 2-19.

33. Ahern, A.; Gómez-Gutiérrez, J.; Aburto-Oropeza, O.; Saldierna-Martínez, R.; Johnson, A.F.; Harada, A.; Sánchez-Uvera, A.; Erisman, B.; Arvizú, D.C.; Burton, R. DNA sequencing of fish eggs and larvae reveals high species diversity and seasonal changes in spawning activity in the southeastern Gulf of California. Mar. Ecol. Prog. Ser. 2018, 592, 159-179. [CrossRef]

34. Bearez, P.; Dettai, A.; Gomon, M.F. Polylepion russelli (Labridae), a Trans-Indo-Pacific Species. Cybium 2013, 37, $305-306$.

35. Victor, B.C.; Alfaro, M.E.; Sorenson, L. Rediscovery of Sagittalarva inornata n. gen., n. comb. (Gilbert, 1890) (Perciformes: Labridae), a long-lost deepwater fish from the eastern Pacific Ocean: A case study of a forensic approach to taxonomy using DNA barcoding. Zootaxa 2013, 3669, 551-570. [CrossRef] [PubMed]

36. Mejía, O.; León-Romero, Y.; Soto-Galera, E. DNA barcoding of the ichthyofauna of Pánuco-Tamesí complex: Evidence for taxonomic conflicts in some groups. Mitochondrial DNA 2012, 23, 471-476. [CrossRef]

37. Venegas, R.D.L.P.; Hueter, R.; Cano, J.G.; Tyminski, J.; Remolina, J.G.; Maslanka, M.; Ormos, A.; Weigt, L.; Carlson, B.; Dove, A. An Unprecedented Aggregation of Whale Sharks, Rhincodon typus, in Mexican Coastal Waters of the Caribbean Sea. PLoS ONE 2011, 6, e18994. [CrossRef]

38. Nogueira, A.F.; Oliveira, C.; Langeani, F.; Netto-Ferreira, A.L. Overlooked biodiversity of mitochondrial lineages in Hemiodus (Ostariophysi, Characiformes). Zool. Scr. 2021, 50, 337-351. [CrossRef]

39. Adelir-Alves, J.; Spier, D.; Gerum, H.L.N.; Machado, L.F.; Spach, H.L.; Boza, B.R.; Oliveira, C. Plectorhinchus macrolepis (Actinopterygii: Haemulidae) in the western Atlantic Ocean. J. Fish Biol. 2019, 95, 1156-1160. [CrossRef] [PubMed]

40. Arruda, P.S.S.; Ferreira, D.C.; Oliveira, C.; Venere, P.C. DNA Barcoding Reveals High Levels of Divergence among Mitochondrial Lineages of Brycon (Characiformes, Bryconidae). Genes 2019, 10, 639. [CrossRef] [PubMed]

41. Caires, R.A.; Santos, W.C.R.d.; Machado, L.; Oliveira, C.; Cerqueira, N.; Rotundo, M.M.; Oliveira, C.; Marceniuk, A.P. The Tonkin Weakfish, Cynoscion similis (Sciaenidae, Perciformes), an Endemic Species of the Amazonas-Orinoco Plume. Acta Amaz. 2019, 49, 197-207. [CrossRef]

42. Carvalho, C.O.; Marceniuk, A.P.; Oliveira, C.; Wosiacki, W.B. Integrative Taxonomy of the Species Complex Haemulon steindachneri (Jordan and Gilbert, 1882) (Eupercaria; Haemulidae) with a Description of a New Species from the Western Atlantic. Zoology 2020, 141, 125782. [CrossRef]

43. de Queiroz, L.J.; Cardoso, Y.P.; Jacot-Des-Combes, C.; Bahechar, I.A.; Lucena, C.A.; Py-Daniel, L.R.; Soares, L.M.S.; Nylinder, S.; Oliveira, C.; Parente, T.E.; et al. Evolutionary units delimitation and continental multilocus phylogeny of the hyperdiverse catfish genus Hypostomus. Mol. Phylogenetics Evol. 2020, 145, 106711. [CrossRef]

44. Ferrette, B.L.D.S.; Domingues, R.R.; Ussami, L.H.F.; Moraes, L.; Magalhães, C.D.O.; De Amorim, A.F.; Hilsdorf, A.W.S.; Oliveira, C.; Foresti, F.; Mendonça, F.F. DNA-based species identification of shark finning seizures in Southwest Atlantic: Implications for wildlife trade surveillance and law enforcement. Biodivers. Conserv. 2019, 28, 4007-4025. [CrossRef]

45. Mateussi, N.T.B.; Melo, B.F.; Oliveira, C. Molecular Delimitation and Taxonomic Revision of the Wimple Piranhacatoprion (Characiformes: Serrasalmidae) with the Description of a New Species. J. Fish Biol. 2020, 97, 668-685. [CrossRef]

46. Mattox, G.M.T.; Souza, C.S.; Toledo-Piza, M.; Britz, R.; Oliveira, C. A New Miniature Species of Priocharax (Teleostei: Characiformes: Characidae) from the Rio Madeira Drainage, Brazil, with Comments on the Adipose Fin in Characiforms. Vertebr. Zool. 2020, 70, 417-433.

47. Hashimoto, S.; Py-Daniel, L.H.R.; Batista, J.S. A molecular assessment of species diversity in Tympanopleura and Ageneiosus catfishes (Auchenipteridae: Siluriformes). J. Fish Biol. 2020, 96, 14-22. [CrossRef] [PubMed]

48. Pereira, L.H.G.; Pazian, M.; Hanner, R.; Foresti, F.; Oliveira, C. DNA barcoding reveals hidden diversity in the Neotropical freshwater fish Piabina argentea (Characiformes: Characidae) from the Upper Paraná Basin of Brazil. Mitochondrial DNA 2011, 22, 87-96. [CrossRef] [PubMed]

49. Castro Paz, F.P.; Batista, J.D.; Porto, J.I.R. DNA Barcodes of Rosy Tetras and Allied Species (Characiformes: Characidae: Hyphessobrycon) from the Brazilian Amazon Basin. PLoS ONE 2014, 9, e98603. [CrossRef]

50. Benzaquem, D.C.; Oliveira, C.; Batista, J.D.S.; Zuanon, J.; Porto, J.I.R. DNA Barcoding in Pencilfishes (Lebiasinidae: Nannostomus) Reveals Cryptic Diversity across the Brazilian Amazon. PLoS ONE 2015, 10, e0112217. [CrossRef]

51. Rossini, B.C.; Oliveira, C.A.M.; de Melo, F.A.G.; Bertaco, V.D.; de Astarloa, J.M.D.; Rosso, J.J.; Foresti, F.; Oliveira, C. Highlighting Astyanax Species Diversity through DNA Barcoding. PLoS ONE 2016, 11, e0167203. [CrossRef]

52. Machado, V.N.; Collins, R.A.; Ota, R.P.; Andrade, M.C.; Farias, I.; Hrbek, T. One thousand DNA barcodes of piranhas and pacus reveal geographic structure and unrecognised diversity in the Amazon. Sci. Rep. 2018, 8, 1-12. [CrossRef] 
53. Carvalho, A.P.C.; Collins, R.A.; Martinez, J.G.; Farias, I.P.; Hrbek, T. From Shallow to Deep Divergences: Mixed Messages from Amazon Basin Cichlids. Hydrobiologia 2019, 832, 317-329. [CrossRef]

54. Hubert, N.; Hadiaty, R.K.; Paradis, E.; Pouyaud, L. Cryptic Diversity in Indo-Australian Rainbowfishes Revealed by DNA Barcoding: Implications for Conservation in a Biodiversity Hotspot Candidate. PLoS ONE 2012, 7, e40627. [CrossRef]

55. Keith, P.; Hadiaty, R.; Hubert, N.; Busson, F.; Lord, C. Three New Species of Lentipes from Indonesia (Gobiidae). Cybium 2014, 38 , 133-146.

56. Lim, H.; Abidin, M.Z.; Pulungan, C.P.; de Bruyn, M.; Nor, S.A.M. DNA Barcoding Reveals High Cryptic Diversity of the Freshwater Halfbeak Genus Hemirhamphodon from Sundaland. PLoS ONE 2016, 11, e0163596. [CrossRef]

57. Beck, S.V.; Carvalho, G.R.; Barlow, A.; Rüber, L.; Tan, H.H.; Nugroho, E.; Wowor, D.; Nor, S.A.M.; Herder, F.; Muchlisin, Z.A.; et al. Plio-Pleistocene phylogeography of the Southeast Asian Blue Panchax killifish, Aplocheilus panchax. PLoS ONE 2017, 12, e0179557. [CrossRef]

58. Dahruddin, H.; Hutama, A.; Busson, F.; Sauri, S.; Hanner, R.; Keith, P.; Hadiaty, R.; Hubert, N. Data from: Revisiting the ichthyodiversity of Java and Bali through DNA barcodes: Taxonomic coverage, identification accuracy, cryptic diversity and identification of exotic species. Mol. Ecol. Resour. 2017, 17, 288-299. [CrossRef]

59. Hutama, A.; Dahruddin, H.; Busson, F.; Sauri, S.; Keith, P.; Hadiaty, R.K.; Hanner, R.; Suryobroto, B.; Hubert, N. Identifying spatially concordant evolutionary significant units across multiple species through DNA barcodes: Application to the conservation genetics of the freshwater fishes of Java and Bali. Glob. Ecol. Conserv. 2017, 12, 170-187. [CrossRef]

60. Conte-Grand, C.; Britz, R.; Dahanukar, N.; Raghavan, R.; Pethiyagoda, R.; Tan, H.H.; Hadiaty, R.K.; Yaakob, N.S.; Rüber, L. Barcoding snakeheads (Teleostei, Channidae) revisited: Discovering greater species diversity and resolving perpetuated taxonomic confusions. PLoS ONE 2017, 12, e0184017. [CrossRef]

61. Farhana, S.N.; Muchlisin, Z.A.; Duong, T.Y.; Tanyaros, S.; Page, L.M.; Zhao, Y.H.; Adamson, E.A.S.; Khaironizam, M.Z.; de Bruyn, M.; Azizah, M.N.S. Exploring Hidden Diversity in Southeast Asia's Dermogenys spp. (Beloniformes: Zenarchopteridae) through DNA Barcoding. Sci. Rep. 2018, 8, 1-11.

62. Shen, Y.; Hubert, N.; Huang, Y.; Wang, X.; Gan, X.; Peng, Z.; He, S. DNA barcoding the ichthyofauna of the Yangtze River: Insights from the molecular inventory of a mega-diverse temperate fauna. Mol. Ecol. Resour. 2019, 19, 1278-1291. [CrossRef]

63. Hubert, N.; Lumbantobing, D.; Sholihah, A.; Dahruddin, H.; Delrieu-Trottin, E.; Busson, F.; Sauri, S.; Hadiaty, R.; Keith, P. Revisiting Species Boundaries and Distribution Ranges of Nemacheilus spp. (Cypriniformes: Nemacheilidae) and Rasbora spp. (Cypriniformes: Cyprinidae) in Java, Bali and Lombok through DNA Barcodes: Implications for Conservation in a Biodiversity Hotspot. Conserv. Genet. 2019, 20, 517-529. [CrossRef]

64. Sholihah, A.; Delrieu-Trottin, E.; Condamine, F.L.; Wowor, D.; Rüber, L.; Pouyaud, L.; Agnèse, J.-F.; Hubert, N. Impact of Pleistocene Eustatic Fluctuations on Evolutionary Dynamics in Southeast Asian Biodiversity Hotspots. Syst. Biol. 2021, syab006. [CrossRef] [PubMed]

65. Sholihah, A.; Delrieu-Trottin, E.; Sukmono, T.; Dahruddin, H.; Risdawati, R.; Elvyra, R.; Wibowo, A.; Kustiati, K.; Busson, F.; Sauri, S.; et al. Disentangling the taxonomy of the subfamily Rasborinae (Cypriniformes, Danionidae) in Sundaland using DNA barcodes. Sci. Rep. 2020, 10, 1-14. [CrossRef] [PubMed]

66. Delrieu-Trottin, E.; Durand, J.; Limmon, G.; Sukmono, T.; Sugeha, H.Y.; Chen, W.-J.; Busson, F.; Borsa, P.; Dahruddin, H.; Sauri, S.; et al. Biodiversity inventory of the grey mullets (Actinopterygii: Mugilidae) of the Indo-Australian Archipelago through the iterative use of DNA-based species delimitation and specimen assignment methods. Evol. Appl. 2020, 13, 1451-1467. [CrossRef]

67. Rüber, L.; Tan, H.H.; Britz, R. Snakehead (Teleostei: Channidae) diversity and the Eastern Himalaya biodiversity hotspot. J. Zool. Syst. Evol. Res. 2019, 58, 356-386. [CrossRef]

68. Chakona, A.; Kadye, W.T.; Bere, T.; Mazungula, D.N.; Vreven, E. Evidence of hidden diversity and taxonomic conflicts in five stream fishes from the Eastern Zimbabwe Highlands freshwater ecoregion. ZooKeys 2018, 768, 69-95. [CrossRef] [PubMed]

69. Iyiola, O.A.; Nneji, L.M.; Mustapha, M.K.; Nzeh, C.G.; Oladipo, S.; Nneji, I.C.; Okeyoyin, A.O.; Nwani, C.D.; Ugwumba, O.A.; Ugwumba, A.A.A.; et al. DNA barcoding of economically important freshwater fish species from north-central Nigeria uncovers cryptic diversity. Ecol. Evol. 2018, 8, 6932-6951. [CrossRef]

70. Sonet, G.; Snoeks, J.; Nagy, Z.T.; Vreven, E.; Boden, G.; Breman, F.C.; Decru, E.; Hanssens, M.; Zamba, A.I.; Jordaens, K.; et al. DNA barcoding fishes from the Congo and the Lower Guinean provinces: Assembling a reference library for poorly inventoried fauna. Mol. Ecol. Resour. 2018, 19, 728-743. [CrossRef]

71. Ward, R.D.; Zemlak, T.S.; Innes, B.H.; Last, P.R.; Hebert, P.D.N. DNA Barcoding Australia's Fish Species. Philos. Trans. R. Soc. B Biol. Sci. 2005, 360, 1847-1857. [CrossRef]

72. Ward, R.D.; Holmes, B.H.; White, W.; Last, P.R. DNA barcoding Australasian chondrichthyans: Results and potential uses in conservation. Mar. Freshw. Res. 2008, 59, 57-71. [CrossRef]

73. Hubert, N.; Paradis, E.; Bruggemann, H.; Planes, S. Community assembly and diversification in Indo-Pacific coral reef fishes. Ecol. Evol. 2011, 1, 229-277. [CrossRef]

74. Hubert, N.; Meyer, C.P.; Bruggemann, H.J.; Guérin, F.; Komeno, R.J.L.; Espiau, B.; Causse, R.; Williams, J.T.; Planes, S. Cryptic Diversity in Indo-Pacific Coral-Reef Fishes Revealed by DNA-Barcoding Provides New Support to the Centre-of-Overlap Hypothesis. PLoS ONE 2012, 7, e28987. [CrossRef]

75. Jaafar, T.N.A.M.; Taylor, M.I.; Nor, S.A.M.; de Bruyn, M.; Carvalho, G.R. DNA Barcoding Reveals Cryptic Diversity within Commercially Exploited Indo-Malay Carangidae (Teleosteii: Perciformes). PLoS ONE 2012, 7, e49623. [CrossRef] [PubMed] 
76. Winterbottom, R.; Hanner, R.H.; Burridge, M.; Zur, M. A cornucopia of cryptic species-A DNA barcode analysis of the gobiid fish genus Trimma (Percomorpha, Gobiiformes). ZooKeys 2014, 381, 79-111. [CrossRef] [PubMed]

77. Durand, J.-D.; Hubert, N.; Shen, K.-N.; Borsa, P. DNA barcoding grey mullets. Rev. Fish Biol. Fish. 2017, 27, 233-243. [CrossRef]

78. Delrieu-Trottin, E.; Williams, J.T.; Pitassy, D.; Driskell, A.; Hubert, N.; Viviani, J.; Cribb, T.; Espiau, B.; Galzin, R.; Kulbicki, M.; et al. A DNA barcode reference library of French Polynesian shore fishes. Sci. Data 2019, 6, 1-8. [CrossRef] [PubMed]

79. Steinke, D.; Zemlak, T.S.; Hebert, P. Barcoding Nemo: DNA-Based Identifications for the Ornamental Fish Trade. PLoS ONE 2009, 4, e6300. [CrossRef] [PubMed]

80. Skelton, P.H.; Swartz, E.R. Walking the tightrope: Trends in African freshwater systematic ichthyology. J. Fish Biol. 2011, 79, 1413-1435. [CrossRef]

81. Adeoba, M.I.; Tesfamichael, S.G.; Yessoufou, K. Preserving the tree of life of the fish family Cyprinidae in Africa in the face of the ongoing extinction crisis. Genome 2019, 62, 170-182. [CrossRef]

82. Montes-Ortiz, L.; Elías-Gutiérrez, M. Water Mite Diversity (Acariformes: Prostigmata: Parasitengonina: Hydrachnidiae) from Karst Ecosystems in Southern of Mexico: A Barcoding Approach. Diversity 2020, 12, 329. [CrossRef]

83. De León, L.F.; Cornejo, A.; Gavilán, R.G.; Aguilar, C. Hidden biodiversity in Neotropical streams: DNA barcoding uncovers high endemicity of freshwater macroinvertebrates at small spatial scales. PLoS ONE 2020, 15, e0231683. [CrossRef] [PubMed]

84. García-Morales, A.E.; Domínguez-Domínguez, O. Cryptic species within the rotifer Lecane bulla (Rotifera: Monogononta: Lecanidae) from North America based on molecular species delimitation. Rev. Mex. Biodivers. 2020, 91, 913116. [CrossRef]

85. Gischler, E.; Gibson, M.A.; Oschmann, W. Giant Holocene Freshwater Microbialites, Laguna Bacalar, Quintana Roo, Mexico. Sedimentology 2008, 55, 1293-1309. [CrossRef]

86. Elías-Gutiérrez, M.; Montes-Ortiz, L. Present Day Kwnoledge on Diversity of Freshwater Zooplancton (Invertebrates) of the Yucatan Peninsula, Using Integrated Taxonomy. Teor. Y Prax. 2018, 14, 31-48.

87. Montes-Ortiz, L.; Elías-Gutiérrez, M. Faunistic survey of the zooplankton community in an oligotrophic sinkhole, Cenote Azul (Quintana Roo, Mexico), using different sampling methods, and documented with DNA barcodes. J. Limnol. 2018, 77, 428-440. [CrossRef]

88. Perry, E.; Velazquez-Oliman, G.; Marin, L. The Hydrogeochemistry of the Karst Aquifer System of the Northern Yucatan Peninsula, Mexico. Int. Geol. Rev. 2002, 44, 191-221. [CrossRef]

89. von Rintelen, K.; von Rintelen, T.; Glaubrecht, M. Molecular Phylogeny and Diversification of Freshwater Shrimps (Decapoda, Atyidae, Caridina) from Ancient Lake Poso (Sulawesi, Indonesia)-The Importance of Being Colourful. Mol. Phylogenetics Evol. 2007, 45, 1033-1041. [CrossRef]

90. Castelin, M.; De Mazancourt, V.; Marquet, G.; Zimmerman, G.; Keith, P. Genetic and morphological evidence for cryptic species in Macrobrachium australe and resurrection of M. ustulatum (Crustacea, Palaemonidae). Eur. J. Taxon. 2017, 289, 1-27. [CrossRef]

91. de Mazancourt, V.; Klotz, W.; Marquet, G.; Mos, B.; Rogers, D.C.; Keith, P. The complex study of complexes: The first wellsupported phylogeny of two species complexes within genus Caridina (Decapoda: Caridea: Atyidae) sheds light on evolution, biogeography, and habitat. Mol. Phylogenetics Evol. 2019, 131, 164-180. [CrossRef]

92. Hernawati, R.; Nurhaman, U.; Busson, F.; Suryobroto, B.; Hanner, R.; Keith, P.; Wowor, D.; Hubert, N. Exploring community assembly among Javanese and Balinese freshwater shrimps (Atyidae, Palaemonidae) through DNA barcodes. Hydrobiology 2019, 847, 647-663. [CrossRef]

93. Garibian, P.G.; Neretina, A.N.; Taylor, D.J.; Kotov, A.A. Partial Revision of the Neustonic Genus Scapholeberis Schoedler, 1858 (Crustacea: Cladocera): Decoding of the Barcoding.Results. PeerJ 2020, 8, e10410. [CrossRef]

94. Yamamoto, A.; Makino, W.; Urabe, J. The taxonomic position of Asian Holopedium (Crustacea: Cladocera) confirmed by morphological and genetic analyses. Limnology 2019, 21, 97-106. [CrossRef]

95. Liu, Y.; Fend, S.V.; Martinsson, S.; Erséus, C. Extensive cryptic diversity in the cosmopolitan sludge worm Limnodrilus hoffmeisteri (Clitellata, Naididae). Org. Divers. Evol. 2017, 17, 477-495. [CrossRef]

96. Chuluunbat, S.; Morse, J.C.; Boldbaatar, S. Caddisflies of Mongolia: Distribution and diversity. Zoosymposia 2016, 10, 96-116. [CrossRef]

97. Wu, R.-W.; Liu, Y.-T.; Wang, S.; Liu, X.-J.; Zanatta, D.; Roe, K.J.; Song, X.-L.; An, C.-T.; Wu, X.-P. Testing the utility of DNA barcodes and a preliminary phylogenetic framework for Chinese freshwater mussels (Bivalvia: Unionidae) from the middle and lower Yangtze River. PLoS ONE 2018, 13, e0200956. [CrossRef] [PubMed]

98. Makino, W.; Machida, R.J.; Okitsu, J.; Usio, N. Underestimated species diversity and hidden habitat preference in Moina (Crustacea, Cladocera) revealed by integrative taxonomy. Hydrobiology 2020, 847, 857-878. [CrossRef]

99. Locke, S.A.; Al-Nasiri, F.S.; Caffara, M.; Drago, F.; Kalbe, M.; Lapierre, A.R.; McLaughlin, J.D.; Nie, P.; Overstreet, R.M.; Souza, G.T.; et al. Diversity, specificity and speciation in larval Diplostomidae (Platyhelminthes: Digenea) in the eyes of freshwater fish, as revealed by DNA barcodes. Int. J. Parasitol. 2015, 45, 841-855. [CrossRef] [PubMed]

100. Locke, S.A.; Caffara, M.; Barčák, D.; Sonko, P.; Tedesco, P.; Fioravanti, M.L.; Li, W. A new species of Clinostomum Leidy, 1856 in East Asia based on genomic and morphological data. Parasitol. Res. 2019, 118, 3253-3265. [CrossRef]

101. Ng, T.H.; Annate, S.; Jeratthitikul, E.; Sutcharit, C.; Limpanont, Y.; Panha, S. Disappearing Apple Snails (Caenogastropoda: Ampullariidae) of Thailand: A Comprehensive Update of Their Taxonomic Status and Distribution. J. Molluscan Stud. 2020, 86, 290-305. [CrossRef] 
102. Vikhrev, I.V.; Konopleva, E.S.; Gofarov, M.Y.; Kondakov, A.V.; Chapurina, Y.E.; Bolotov, I.N. A Tropical Biodiversity Hotspot under the New Threat: Discovery and DNA Barcoding of the Invasive Chinese Pond Mussel Sinanodonta Woodiana in Myanmar. Trop. Conserv. Sci. 2017, 10, 1-11. [CrossRef]

103. Lima, F.D.; Berbel-Filho, W.M.; Leite, T.S.; Rosas, C.; Lima, S.M.Q. Occurrence of Octopus insularis Leite and Haimovici, 2008 in the Tropical Northwestern Atlantic and implications of species misidentification to octopus fisheries management. Mar. Biodivers. 2017, 47, 723-734. [CrossRef]

104. Rosas-Luis, R.; Badillo, M.D.L.J.; Elena, L.M.; Morillo-Velarde, P.S. Food and feeding habits of Octopus insularis in the Veracruz Reef System National Park and confirmation of its presence in the southwest Gulf of Mexico. Mar. Ecol. 2019, 40, e12535. [CrossRef]

105. Caffara, M.; Locke, S.A.; Echi, P.C.; Halajian, A.; Benini, D.; Luus-Powell, W.J.; Tavakol, S.; Fioravanti, M.L. A morphological and molecular study of Clinostomid metacercariae from African fish with a redescription of Clinostomum tilapiae. Parasitology 2017, 144, 1519-1529. [CrossRef]

106. Chibwana, F.D.; Blasco-Costa, I.; Georgieva, S.; Hosea, K.M.; Nkwengulila, G.; Scholz, T.; Kostadinova, A. A first insight into the barcodes for African diplostomids (Digenea: Diplostomidae): Brain parasites in Clarias gariepinus (Siluriformes: Clariidae). Infect. Genet. Evol. 2013, 17, 62-70. [CrossRef] [PubMed]

107. Laidemitt, M.R.; Brant, S.V.; Mutuku, M.W.; Mkoji, G.M.; Loker, E.S. The diverse echinostomes from East Africa: With a focus on species that use Biomphalaria and Bulinus as intermediate hosts. Acta Trop. 2019, 193, 38-49. [CrossRef] [PubMed]

108. Webster, B.; Webster, J.P.; Gouvras, A.; Garba, A.; Lamine, M.S.; Diaw, O.T.; Seye, M.M.; Tchuenté, L.-A.T.; Simoonga, C.; Mubila, L.; et al. DNA 'barcoding' of Schistosoma mansoni across sub-Saharan Africa supports substantial within locality diversity and geographical separation of genotypes. Acta Trop. 2013, 128, 250-260. [CrossRef] [PubMed]

109. Stothard, J.R.; Ameri, H.; Khamis, I.S.; Blair, L.; Nyandindi, U.S.; Kane, R.A.; Johnston, D.A.; Webster, B.; Rollinson, D. Parasitological and malacological surveys reveal urogenital schistosomiasis on Mafia Island, Tanzania to be an imported infection. Acta Trop. 2013, 128, 326-333. [CrossRef]

110. Alcántar-Escalera, F.A.; García-Varela, M.; Vázquez-Domínguez, E.; de León, G.P. Using DNA Barcoding to Link Cystacanths and Adults of the Acanthocephalan Polymorphus brevis in Central Mexico. Mol. Ecol. Resour. 2013, 13, 1116-1124.

111. Lawton, S.P.; Allan, F.; Hayes, P.M.; Smit, N.J. DNA barcoding of the medically important freshwater snail Physa acuta reveals multiple invasion events into Africa. Acta Trop. 2018, 188, 86-92. [CrossRef]

112. Angyal, D.; Balázs, G.; Krízsik, V.; Herczeg, G.; Fehér, Z. Molecular and morphological divergence in a stygobiont gastropod lineage (Truncatelloidea, Moitessieriidae, Paladilhiopsis) within an isolated karstic area in the Mecsek Mountains (Hungary). J. Zool. Syst. Evol. Res. 2018, 56, 493-504. [CrossRef]

113. Elderkin, C.L.; Clewing, C.; Ndeo, O.W.; Albrecht, C. Molecular Phylogeny and DNA Barcoding Confirm Cryptic Species in the African Freshwater Oyster Etheria elliptica Lamarck, 1807 (Bivalvia: Etheriidae). Biol. J. Linn. Soc. 2016, 118, 369-381. [CrossRef]

114. Carr, C.M.; Hardy, S.M.; Brown, T.M.; Macdonald, T.A.; Hebert, P. A Tri-Oceanic Perspective: DNA Barcoding Reveals Geographic Structure and Cryptic Diversity in Canadian Polychaetes. PLoS ONE 2011, 6, e22232. [CrossRef] [PubMed]

115. Villalobos-Guerrero, T.F.; Carrera-Parra, L.F. Redescription of Alitta succinea (Leuckart, 1847) and reinstatement of A. acutifolia (Ehlers, 1901) n. comb. based upon morphological and molecular data (Polychaeta: Nereididae). Zootaxa 2015, 3919, 157-178. [CrossRef]

116. Salazar-Silva, P.; Carrera-Parra, L.F. Revision of Lepidonopsis humilis (Augener, 1922) and description of L. barnichae sp. nov. (Annelida: Polychaeta: Polynoidae) based upon morphological and molecular characters. Zootaxa 2014, 3790, 555-566. [CrossRef] [PubMed]

117. Carrera-Parra, L.F.; Salazar-Vallejo, S.I. Redescriptions of Eunice filamentosa and E. denticulata and Description of E. tovarae n. sp. (Polychaeta: Eunicidae), Highlighted with Morphological and Molecular Data. Zootaxa 2011, 2880, 51-64. [CrossRef]

118. Keith, P.; Dahruddin, H.; Limmon, G.; Hubert, N. A New Species of Schismatogobius (Teleostei: Gobiidae) from Halmahera (Indonesia). Cybium 2018, 42, 195-200.

119. Keith, P.; Lord, C.; Darhuddin, H.; Limmon, G.; Sukmono, T.; Hadiaty, R.; Hubert, N. Schismatogobius (Gobiidae) from Indonesia, with Description of Four New Species. Cybium 2017, 41, 195-211.

120. Gutiérrez-Aguirre, M.A.; Cervantes-Martínez, A.; Elías-Gutiérrez, M.; Lugo-Vázquez, A. Remarks on Mastigodiaptomus (Calanoida: Diaptomidae) from Mexico using integrative taxonomy, with a key of identification and three new species. PeerJ 2020, 8, e8416. [CrossRef] [PubMed]

121. Andrade-Sossa, C.; Buitron-Caicedo, L.; Elías-Gutiérrez, M. A new species of Scapholeberis Schoedler, 1858 (Anomopoda: Daphniidae: Scapholeberinae) from the Colombian Amazon basin highlighted by DNA barcodes and morphology. Peer 2020,8 , e9989. [CrossRef]

122. Elías-Gutiérrez, M.; Valdez-Moreno, M. A New Cryptic Species of Leberis Smirnov, 1989 (Crustacea, Cladocera, Chydoridae) from the Mexican Semi-Desert Region, Highlighted by DNA Barcoding. Hidrobiologica 2008, 18, 63-74.

123. Keith, P.; Mennesson, M.I.; Sauri, S.; Busson, F.; Delrieu-Trottin, E.; Limmon, G.; Dahruddin, H.; Hubert, N. Giuris (Teleostei: Eleotridae) from Indonesia, with Description of a New Species. Cybium 2020, 44, 317-329.

124. Escobar L, M.D.; Ota, R.P.; Machado-Allison, A.; Andrade-López, J.; Farias, I.P.; Hrbek, T. A new species of Piaractus (Characiformes: Serrasalmidae) from the Orinoco Basin with a redescription of Piaractus brachypomus. J. Fish Biol. 2019, 95, 411-427. [CrossRef] 
125. Ota, R.P.; Machado, V.N.; Andrade, M.C.; Collins, R.A.; Farias, I.P.; Hrbek, T. Integrative Taxonomy Reveals a New Species of Pacu (Characiformes: Serrasalmidae: Myloplus) from the Brazilian Amazon. Neotrop. Ichthyol. 2020, 18. [CrossRef]

126. Bekker, E.I.; Karabanov, D.; Galimov, Y.R.; Kotov, A.A. DNA Barcoding Reveals High Cryptic Diversity in the North Eurasian Moina Species (Crustacea: Cladocera). PLoS ONE 2016, 11, e0161737. [CrossRef]

127. Elías-Gutiérrez, M.; Juracka, P.J.; Montoliu-Elena, L.; Miracle, M.R.; Petrusek, A.; Korinek, V. Who Is Moina micrura? Redescription of One of the Most Confusing Cladocerans from Terra Typica, Based on Integrative Taxonomy. Limnetica 2019, 38, 227-252.

128. Quiroz-Vázquez, P.; Elías-Gutiérrez, M. A New Species of the Freshwater Cladoceran Genus Scapholeberis Schoedler, 1858 (Cladocera: Anomopoda) from the Semidesert Northern Mexico, Highlighted by DNA Barcoding. Zootaxa 2009, $2236,50-64$. [CrossRef]

129. Mercado-Salas, N.F.; Khodami, S.; Kihara, T.C.; Elías-Gutiérrez, M.; Arbizu, P.M. Genetic Structure and Distributional Patterns of the Genus Mastigodiaptomus (Copepoda) in Mexico, with the Description of a New Species from the Yucatan Peninsula. Arthropod Syst. Phylogeny 2018, 76, 487-507.

130. Gutiérrez-Aguirre, M.A.; Cervantes-Martínez, A. A new species of Mastigodiaptomus Light, 1939 from Mexico, with notes of species diversity of the genus (Copepoda, Calanoida, Diaptomidae). ZooKeys 2016, 637, 61-79. [CrossRef]

131. Pegg, G.G.; Sinclair, B.; Briskey, L.; Aspden, W.J. MtDNA barcode identification of fish larvae in the southern Great Barrier Reef-Australia. Sci. Mar. 2006, 70, 7-12. [CrossRef]

132. Hubert, N.; Delrieu-Trottin, E.; Irisson, J.-O.; Meyer, C.; Planes, S. Identifying coral reef fish larvae through DNA barcoding: A test case with the families Acanthuridae and Holocentridae. Mol. Phylogenetics Evol. 2010, 55, 1195-1203. [CrossRef] [PubMed]

133. Hubert, N.; Espiau, B.; Meyer, C.; Planes, S. Identifying the ichthyoplankton of a coral reef using DNA barcodes. Mol. Ecol. Resour. 2015, 15, 57-67. [CrossRef]

134. Ko, H.-L.; Wang, Y.-T.; Chiu, T.-S.; Lee, M.-A.; Leu, M.-Y.; Chang, K.-Z.; Chen, W.-Y.; Shao, K.-T. Evaluating the Accuracy of Morphological Identification of Larval Fishes by Applying DNA Barcoding. PLoS ONE 2013, 8, e53451. [CrossRef]

135. Azmir, I.A.; Esa, Y.; Amin, S.M.N.; Yasin, I.S.M.; Yusof, F.Z.M.; Azmir, I.A.; Esa, Y.; Amin, S.M.N.; Yasin, I.S.M.; Yusof, F.Z.M. Identification of larval fish in mangrove areas of Peninsular Malaysia using morphology and DNA barcoding methods. J. Appl. Ichthyol. 2017, 33, 998-1006. [CrossRef]

136. Collet, A.; Durand, J.-D.; Desmarais, E.; Cerqueira, F.; Cantinelli, T.; Valade, P.; Ponton, D. DNA barcoding post-larvae can improve the knowledge about fish biodiversity: An example from La Reunion, SW Indian Ocean. Mitochondrial DNA Part A 2018, 29, 905-918. [CrossRef] [PubMed]

137. Mariac, C.; Vigouroux, Y.; Duponchelle, F.; García-Dávila, C.; Nunez, J.; Desmarais, E.; Renno, J. Metabarcoding by capture using a single COI probe (MCSP) to identify and quantify fish species in ichthyoplankton swarms. PLoS ONE 2018, 13, e0202976. [CrossRef] [PubMed]

138. Steinke, D.; Connell, A.D.; Hebert, P.D. Linking adults and immatures of South African marine fishes. Genome 2016, 59, 959-967. [CrossRef] [PubMed]

139. Zhou, X.; Jacobus, L.M.; DeWalt, R.E.; Adamowicz, S.J.; Hebert, P.D.N. Ephemeroptera, Plecoptera, and Trichoptera fauna of Churchill (Manitoba, Canada): Insights into biodiversity patterns from DNA barcoding. J. N. Am. Benthol. Soc. 2010, $29,814-837$. [CrossRef]

140. Carew, M.E.; Pettigrove, V.; Cox, R.L.; Hoffmann, A.A. DNA identification of urban Tanytarsini chironomids (Diptera: Chironomidae). J. N. Am. Benthol. Soc. 2007, 26, 587-600. [CrossRef]

141. Kusche, H.; Hanel, R. Consumers of mislabeled tropical fish exhibit increased risks of ciguatera intoxication: A report on substitution patterns in fish imported at Frankfurt Airport, Germany. Food Control 2021, 121, 107647. [CrossRef]

142. Wong, E.H.K.; Hanner, R. DNA Barcoding Detects Market Substitution in North American Seafood. Food Res. Int. 2008, 41, 828-837. [CrossRef]

143. Sarmiento-Camacho, S.; Valdez-Moreno, M. DNA barcode identification of commercial fish sold in Mexican markets. Genome 2018, 61, 457-466. [CrossRef]

144. Chang, C.H.; Lin, H.Y.; Ren, Q.; Lin, Y.S.; Shao, K.T. DNA Barcode Identification of Fish Products in Taiwan: GovernmentCommissioned Authentication Cases. Food Control 2016, 66, 38-43. [CrossRef]

145. Günther, B.; Raupach, M.J.; Knebelsberger, T. Full-length and mini-length DNA barcoding for the identification of seafood commercially traded in Germany. Food Control 2017, 73, 922-929. [CrossRef]

146. Christiansen, H.; Fournier, N.; Hellemans, B.; Volckaert, F.A. Seafood substitution and mislabeling in Brussels' restaurants and canteens. Food Control 2018, 85, 66-75. [CrossRef]

147. Vandamme, S.G.; Griffiths, A.M.; Taylor, S.-A.; Di Muri, C.; Hankard, E.A.; Towne, J.A.; Watson, M.; Mariani, S. Sushi barcoding in the UK: Another kettle of fish. PeerJ 2016, 4, e1891. [CrossRef] [PubMed]

148. Cawthorn, D.-M.; Baillie, C.; Mariani, S. Generic names and mislabeling conceal high species diversity in global fisheries markets. Conserv. Lett. 2018, 11, e12573. [CrossRef]

149. Delpiani, G.; Delpiani, S.; Antoni, M.D.; Ale, M.C.; Fischer, L.; Lucifora, L.; de Astarloa, J.D. Are we sure we eat what we buy? Fish mislabelling in Buenos Aires province, the largest sea food market in Argentina. Fish. Res. 2020, 221, 105373. [CrossRef]

150. Valdez-Moreno, M.; Quintal-Lizama, C.; Gómez-Lozano, R.; García-Rivas, M.D.C. Monitoring an Alien Invasion: DNA Barcoding and the Identification of Lionfish and Their Prey on Coral Reefs of the Mexican Caribbean. PLoS ONE 2012, 7, e36636. [CrossRef] 
151. Valdez-Moreno, M.; Ivanova, N.V.; Elías-Gutiérrez, M.; Pedersen, S.L.; Bessonov, K.; Hebert, P.D.N. Using eDNA to biomonitor the fish community in a tropical oligotrophic lake. PLoS ONE 2019, 14, e0215505. [CrossRef]

152. Hebert, P.D.N.; Braukmann, T.W.A.; Prosser, S.W.J.; Ratnasingham, S.; Dewaard, J.R.; Ivanova, N.V.; Janzen, D.H.; Hallwachs, W.; Naik, S.; Sones, J.E.; et al. A Sequel to Sanger: Amplicon sequencing that scales. BMC Genom. 2018, 19, 219. [CrossRef] [PubMed]

153. Pomerantz, A.; Penafiel, N.; Arteaga, A.; Bustamante, L.; Pichardo, F.; Coloma, L.A.; Barrio-Amoros, C.L.; Salazar-Valenzuela, D.; Prost, S. Real-Time DNA Barcoding in a Rainforest Using Nanopore Sequencing: Opportunities for Rapid Biodiversity Assessments and Local Capacity Building. Gigascience 2018, 7, giy033. [CrossRef]

154. Srivathsan, A.; Baloglu, B.; Wang, W.; Tan, W.X.; Bertrand, D.; Ng, A.H.Q.; Boey, E.J.H.; Koh, J.J.Y.; Nagarajan, N.; Meier, R. A Minion-Based Pipeline for Fast and Cost-Effective DNA Barcoding. Mol. Ecol. Resour. 2018, 18, 1035-1049. [CrossRef] [PubMed]

155. Berry, T.E.; Osterrieder, S.K.; Murray, D.C.; Coghlan, M.L.; Richardson, A.J.; Grealy, A.K.; Stat, M.; Bejder, L.; Bunce, M. DNA metabarcoding for diet analysis and biodiversity: A case study using the endangered Australian sea lion (Neophoca cinerea). Ecol. Evol. 2017, 7, 5435-5453. [CrossRef]

156. Suter, L.; Polanowski, A.; Clarke, L.J.; Kitchener, J.; Deagle, B.E. Capturing open ocean biodiversity: Comparing environmental DNA metabarcoding to the continuous plankton recorder. Mol. Ecol. 2020. [CrossRef]

157. Zamora-Terol, S.; Novotny, A.; Winder, M. Reconstructing Marine Plankton Food Web Interactions Using DNA Metabarcoding. Mol. Ecol. 2020, 29, 3380-3395. [CrossRef]

158. Mauffrey, F.; Cordier, T.; Apothéloz-Perret-Gentil, L.; Cermakova, K.; Merzi, T.; Delefosse, M.; Blanc, P.; Pawlowski, J. Benthic monitoring of oil and gas offshore platforms in the North Sea using environmental DNA metabarcoding. Mol. Ecol. 2020. [CrossRef] [PubMed]

159. Elbrecht, V.; Vamos, E.E.; Meissner, K.; Aroviita, J.; Leese, F. Assessing strengths and weaknesses of DNA metabarcoding-based macroinvertebrate identification for routine stream monitoring. Methods Ecol. Evol. 2017, 8, 1265-1275. [CrossRef]

160. Andújar, C.; Arribas, P.; Yu, D.W.; Vogler, A.P.; Emerson, B.C. Why the COI barcode should be the community DNA metabarcode for the metazoa. Mol. Ecol. 2018, 27, 3968-3975. [CrossRef]

161. Deiner, K.; Bik, H.M.; Mächler, E.; Seymour, M.; Lacoursière-Roussel, A.; Altermatt, F.; Creer, S.; Bista, I.; Lodge, D.M.; De Vere, N.; et al. Environmental DNA metabarcoding: Transforming how we survey animal and plant communities. Mol. Ecol. 2017, 26, 5872-5895. [CrossRef]

162. Rees, H.C.; Maddison, B.C.; Middleditch, D.J.; Patmore, J.R.M.; Gough, K.C. Review the Detection of Aquatic Animal Species Using Environmental DNA-A Review of eDNA as a Survey Tool in Ecology. J. Appl. Ecol. 2014, 51, 1450-1459. [CrossRef]

163. Valentini, A.; Taberlet, P.; Miaud, C.; Civade, R.; Herder, J.; Thomsen, P.F.; Bellemain, E.; Besnard, A.; Coissac, E.; Boyer, F.; et al. Data from: Next-generation monitoring of aquatic biodiversity using environmental DNA metabarcoding. Mol. Ecol. 2016, 25, 929-942. [CrossRef] [PubMed]

164. Collins, R.A.; Bakker, J.; Wangensteen, O.S.; Soto, A.Z.; Corrigan, L.; Sims, D.W.; Genner, M.J.; Mariani, S. Non-specific amplification compromises environmental DNA metabarcoding with COI. Methods Ecol. Evol. 2019, 10, 1985-2001. [CrossRef]

165. Cordier, T.; Esling, P.; Lejzerowicz, F.; Visco, J.A.; Ouadahi, A.; Martins, C.I.M.; Cedhagen, T.; Pawlowski, J. Predicting the Ecological Quality Status of Marine Environments from eDNA Metabarcoding Data Using Supervised Machine Learning. Environ. Sci. Technol. 2017, 51, 9118-9126. [CrossRef]

166. Mächler, E.; Walser, J.; Altermatt, F. Decision-making and best practices for taxonomy-free environmental DNA metabarcoding in biomonitoring using Hill numbers. Mol. Ecol. 2020. [CrossRef]

167. Van Der Walt, K.; Mäkinen, T.; Swartz, E.; Weyl, O. DNA barcoding of South Africa's ornamental freshwater fish-Are the names reliable? Afr. J. Aquat. Sci. 2017, 42, 155-160. [CrossRef]

168. Collins, R.A.; Armstrong, K.; Meier, R.; Yi, Y.; Brown, S.; Cruickshank, R.H.; Keeling, S.; Johnston, C. Barcoding and Border Biosecurity: Identifying Cyprinid Fishes in the Aquarium Trade. PLoS ONE 2012, 7, e28381. [CrossRef] [PubMed]

169. Curry, C.J.; Gibson, J.F.; Shokralla, S.; Hajibabaei, M.; Baird, D.J. Identifying North American freshwater invertebrates using DNA barcodes: Are existing COI sequence libraries fit for purpose? Freshw. Sci. 2018, 37, 178-189. [CrossRef]

170. Jo, H.; Gim, J.A.; Jeong, K.S.; Kim, H.S.; Joo, G.J. Application of DNA Barcoding for Identification of Freshwater Carnivorous Fish Diets: Is Number of Prey Items Dependent on Size Class for Micropterus Salmoides? Ecol. Evol. 2014, 4, 219-229. [CrossRef]

171. Jo, H.; Ventura, M.; Vidal, N.; Gim, J.S.; Buchaca, T.; Barmuta, L.A.; Jeppesen, E.; Joo, G.J. Discovering Hidden Biodiversity: The Use of Complementary Monitoring of Fish Diet Based on DNA Barcoding in Freshwater Ecosystems. Ecol. Evol. 2016, 6, 219-232. [CrossRef] 